\title{
Reshaping health care governance using pilot projects as public policy implementation instruments
}

The case of integrated care pilot projects for chronic patients in Belgium Mélanie De Winter

\section{OpenEdition}

\section{Journals}

\section{Electronic version}

URL: https://journals.openedition.org/irpp/1422

DOI: 10.4000/irpp.1422

ISSN: 2706-6274

Publisher

International Public Policy Association

\section{Printed version}

Date of publication: 15 December 2020

Number of pages: $317-341$

ISSN: 2679-3873

Electronic reference

Mélanie De Winter, "Reshaping health care governance using pilot projects as public policy

implementation instruments", International Review of Public Policy [Online], 2:3 | 2020, Online since 15

December 2020, connection on 07 September 2021. URL: http://journals.openedition.org/irpp/1422 ; DOI: https://doi.org/10.4000/irpp.1422

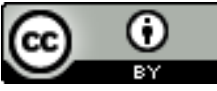

International Review of Public Policy is licensed under a Creative Commons Attribution 4.0 International. 


\section{Reshaping health care governance using pilot projects as public policy implementation instruments}

The case of integrated care pilot projects for chronic patients in Belgium

\section{Mélanie De Winter}

Centre de recherches et d'interventions sociologiques, Liège Université.

\section{Abstract}

Pilot projects are often used to test innovations; however, pilot projects, viewed as tools, are rarely addressed as an object for research. This paper, in which pilot projects are viewed as public policy instruments producing specific effects, addresses the research question: how does the use of multidisciplinary pilot projects as experimentation and implementation instruments reshape modes of public governance in the Belgian health sector in a context of transition and ongoing devolution? An ethnographic study was conducted, focusing on the specific case of the Belgian joint plan, "Integrated Care for Better Health", which targets chronic patients and was intended to initiate a major transition from a fragmented to an integrated care system for chronic patients. The analysis concerns the specific implementation modalities designed by the authorities, which consisted of the launch of pilot projects involving professionals in the field coming from different sectors in an iterative and incremental co-creation process. This choice caused new vertical interdependences to emerge between the levels of the health care system, transforming the roles of both the authorities and hands-on professionals involved; it also denoted a transition towards a more negotiated governance, in the course of which several types of knowledge and evidence have been mobilised.

\section{Keywords}

pilot project, policy instrument, integrated care, knowledge, public policy implementation 


\section{Introduction}

Pilot projects are often used in a variety of sectors in innovative contexts. In the scientific literature, one can find numerous articles relating the results of a specific pilot project in a particular sector, whereas the literature analysing the pilot project tool as an object for research is much rarer (Pinson, 2005). In other words, research focuses generally on the experiment conducted as part of the pilot project under study, and not on the pilot project tool as a phenomenon per se, which should, nevertheless, also be worthy of scientific attention (Vreugdenhil et al., 2010).

The pilot project is a specific work method, fulfilling a function of experimentation, which is mobilised in a plethora of sectors and allows a learning while doing approach (Kay \& Boxall, 2015; Lee, 1999). This tool offers the possibility to test the innovation at stake in real-world settings at small and controlled scales, which limits the impact of potential failure or negative side effects (Vreugdenhil \& Ker Rault, 2010). Furthermore, the actions undertaken as part of the experiment are expected to be more reversible (Musselin, 2005; Zurlo \& Nunes, 2016) and, for this reason, are supposed to be less frightening for the stakeholders involved.

Therefore, pilot projects are often used by policy makers in innovative contexts (Vreugdenhil et al., 2010), to learn from the experimentation carried out (Engström \& Lidelöw, 2015) and to create new knowledge and produce evidence for policy-making (Sanderson, 2002; Vreugdenhil $\&$ Ker Rault, 2010). They are thus expected to help orient future political action and policy development. In this way, the pilot project constitutes a tool for, "improving the effectiveness of policy responses" (Sanderson, 2002, p. 4). The purpose is to work collaboratively (Zurlo \& Nunes, 2016) in order to identify what works in what context (Sanderson, 2002; Vreugdenhil \& Ker Rault, 2010).

Nevertheless, Sanderson (2002) argues that politicians/policy makers often divert pilot projects from their primary function of experimenting and learning. Instead, they only use them as a means of exemplification, demonstration and legitimation when the produced evidence corroborates their political priorities. Actually, according to Cook (1997, p. 40, cited in Sanderson, 2002, p. 5), "the politician's prime goal is to be re-elected rather than to respect technical evidence", which constitutes political short-termism. On the contrary, experimentations conducted as part of pilot projects are often long-term endeavours, which require, in contrast, sufficient time to produce effects from which lessons can be learnt (Sanderson, 2002).

As collective experiments (Zurlo \& Nunes, 2016), pilot projects also gather a diversity of stakeholders who have to interact and work together to create new solutions to solve a problem by exchanging their respective knowledge and stances (Segrestin, 2004): as the old proverb says: two heads are better than one. In this way, due to their inherent interactionist nature (Pinson, 2005), "pilot projects are [also] means to establish communication between actors that usually do not cooperate" (Vreugdenhil \& Ker Rault, 2010, p. 122). This explains why, besides experimentation, pilot projects can also be mobilised for policy implementation (Vreugdenhil et al., 2010) when, for example, the policy programme cannot be implemented in a conventional manner. In this case, the use of the pilot project tool provides a means for a staged implementation process (Vreugdenhil \& Ker Rault, 2010), leveraging the collaborative dynamic between involved stakeholders in order to, "pragmatically put fully developed policy into practice" (Vreugdenhil et al., 2010, p. 13).

In this paper, which in a certain sense echoes the old, but not outdated, research of Pinson (2005) on urban projects, pilot projects are not analysed only as simple tools or work methods but as specific public policy instruments (Lascoumes \& Le Galès, 2005). Accordingly, before 
presenting the research question addressed in this paper, it seems appropriate to dwell a little on the very notion of public policy instruments in order to understand the reasoning behind the formulation of this research question as well as its relevance. It would nevertheless seem illusory and unnecessary to develop all the plethora of different approaches and taxonomies that were developed regarding policy instruments in the scientific literature. Therefore, in the next section, I will select the elements which seem relevant for analysing the central object of this article: the pilot project phenomenon.

\section{Policy instruments: contributions of scientific literature and research question}

Policy instruments are one of the three main components of a public policy, the two others being the policy foundations, referring to the aims pursued via the policy, and the public targeted (Hassenteufel, 2011). Policy instruments constitute the means by which ideas stabilised during the policy formulation process are supposed to be implemented (Ali, 2013). They can be viewed as "a set of techniques by which governmental authorities wield their power in attempting to ensure support and effect (or prevent) social change" (Vedung, 1998, p. 21, cited in Borrás \& Edquist, 2019, p. 215). So, "policy instruments are techniques of governance that, one way or another, involve the utilization of state authority or its conscious limitation" (Howlett, 2005, p. 31).

The scientific literature pertaining to policy instruments revolves around three main topics:

- the numerous categorisations and typologies of policy instruments produced over time in this field of research, e.g., the well-known NATO1-scheme developed by Christopher Hood (Hood et al., 2007) or the "carrots, sticks and sermons-approach" developed by Vedung (Vabo \& Røiseland, 2012);

- the way instruments are chosen by governments through the identification of instrument choice patterns; and, more recently

- the way instruments are combined in specific mixes (Capano et al., 2020; Howlett et al., 2018). (This third topic will not be addressed in this paper).

If listing all the existing categorisations and typologies of policy instruments would not be of much use in the case at hand, the interesting distinction between substantive and procedural instruments should be mentioned. Substantive instruments are "policy techniques or mechanisms designed to directly or indirectly affect the production, consumption and distribution of different kinds of goods and services in society" (Howlett et al., 2018, p. 7), whereas procedural instruments, "on the other hand, affect production, consumption and distribution processes only indirectly, if at all, and instead are concerned with altering aspects of a governments own workings" (Howlett et al., 2018, p. 9). Due to the above-mentioned elements that characterise the pilot project, the latter can be viewed as a procedural instrument which help define the content of substantive policies.

Regarding the choice of public policy instruments, the theoretical framework of Lascoumes and Le Galès (2005), which belongs to the sociology of public action, is particularly relevant to the case at hand. These two scholars analysed public action and state governance modes by focusing on public policy instrumentation, which constitutes "a means of orienting relations between political society (via the administrative executive) and civil society (via its administered 
subjects)" (Lascoumes \& Le Gales, 2007, p. 1). They define public policy instrumentation as:

the set of problems posed by the choice and use of instruments (techniques, methods of operation, devices) that allow government policy to be made material and operational. Another way of formulating the issue is to say that it involves not only understanding the reasons that drive towards retaining one instrument rather than another, but also envisaging the effects produced by these choices. (2007, p. 4)

As much as the objectives of a public policy, instrumentation is also a political choice (Howlett, 1991; Howlett et al., 2018) because the choice of modes of action, and therefore of instruments, which can be the subject of political conflicts, will partly structure the process and its results and have an impact on power relations (Lascoumes \& Le Galès, 2005). Interestingly:

a public policy instrument constitutes a device that is both technical and social, that organizes specific social relations between the state and those it is addressed to, according to the representations and meanings it carries. It is a particular type of institution, a technical device with the generic purpose of carrying a concrete concept of the politics/society relationship and sustained by a concept of regulation. (Lascoumes \& Le Gales, 2007, p. 4)

This means that the choice of one instrument over another is not trivial and is not only a technical choice, as suggested in the functionalist approach. Instead, instruments structure public action and produce specific, sometimes unexpected, effects, independent of the primary purposes assigned to them (Borrás \& Edquist, 2019; Lascoumes \& Le Galès, 2005). Indeed, as Lascoumes \& Le Galès (2007, p. 4) put it, "public policy instruments are not tools with perfect axiological neutrality, equally available: on the contrary, they are bearers of values, fuelled by one interpretation of the social and by precise notions of the mode of regulation envisaged".

In view of all this, this paper intends to contribute to the scant literature focusing on the pilot project phenomenon as well as, to some extent, on the public action instruments studies by providing an in-depth analysis of the consequences of the use of this specific instrument by policy-makers in terms of public governance. The focus here is on the specific case of the implementation of a public policy in the Belgian health sector via the launch of pilot projects simultaneously used as experimentation and implementation instruments: the "Integrated Care for Better Health" (IC4BH) joint plan targeting chronic patients. Therefore, this paper is based on the following research question: how does the use of multidisciplinary pilot projects as experimentation and implementation instruments reshape modes of public governance in the Belgian health sector in a context of transition and ongoing devolution?

The choice of analysing this specific case comes from the fact that it can be noticed that for the past fifteen years there has been an increasingly systematic recourse to the use of pilot projects by the Belgian authorities to implement new public policies, especially in the health care sector. One can mention, inter alia: "therapeutic projects" and "psy 107" projects in the mental health sector; "multidisciplinary local networks" for diabetics (Type 2) and patients with renal insufficiency; mobile health projects and "integrated care" pilot projects for chronic patients launched as a means to implement the joint plan entitled "Integrated Care for Better Health" (IC4BH), which was approved in October 2015.

The interest of focusing on this case is twofold:

- lessons can be learnt regarding this way of operating at the national Belgian level, which is of interest for the Belgian authorities; and 
- it may be of interest at an international level for countries that are tempted to resort to pilot projects as part of the implementation of their public policies.

\section{Background}

\section{The Belgian Healthcare System}

The current Bismarckian Belgian health care system combines a compulsory health insurance, which is part of the global Belgian social protection system, with a non-mandatory supplementary health insurance, both of which are based on the principle of solidarity (Saltman et al., 2004). The entire Belgian population is entitled to medical care, either as a beneficiary or as a dependent (spouses, children, grandchildren). The supplementary health insurance is provided by sickness funds upon payment of insurance premiums and gives access to additional benefits, reimbursements and services.

Sickness funds play the role of intermediaries between the National Institute for Health and Disability Insurance (NIHDI), i.e., the parastatal institution in charge of managing the national health care budget, the patients and their health practitioners regarding the reimbursement of medical expenditures. In order to ensure their rights to compulsory health insurance benefits, beneficiaries have to affiliate with a sickness fund of their choice.

In Belgium, the majority of physicians are self-employed and remunerated on a fee-for-service basis (OECD \& European Observatory on Health Systems and Policies, 2017): they are paid for each service performed. Patients pay their medical costs upfront and, in exchange, receive a certificate that proves the payment has been made. Upon presentation of this document, patients can be partly refunded by their sickness funds. The amount of reimbursement covered by compulsory insurance is set by the NIHDI and listed in an official "nomenclature" as is the case with all reimbursement rates related to every refundable medical act. The part that is not reimbursed, the proportion assumed by patients, is called the user fee or patient fee (Service Public Federal Securité Sociale, 2016).

In certain specific cases (low income, disability, etc.), a third-party payer system is applied. ${ }^{2}$ Then, patients only pay their user fees to their practitioners and, "the reimbursement rates are applied directly" (Federal Public Service Social Security, 2012, p. 44). Practitioners receive the rest of their fees, the amount covered by compulsory insurance, from their patients' sickness funds. The difference here is that patients pay nothing upfront.

Belgium applies the principle of freedom of choice (OECD \& European Observatory on Health Systems and Policies, 2017), which is a common feature of social health insurance systems (Saltman et al., 2004). Sometimes, this leads to an over-consumption of health care and, consequently, an increase in healthcare expenditure (Palier, 2017). Specifically, the principle of freedom of choice means that, "patients can select their provider" (Saltman et al., 2004, p. 249). They are free to choose their sickness fund, their doctor(s) (GPs and specialists) and to go to the hospital of their choice. In other words, GPs do not play the role of gatekeepers as they do in national health care systems (such as in the UK and Sweden). In the latter, patients first visit their GP, before being allowed to consult a specialist (Palier, 2017; Saltman et al., 2004).

Alternatively, patients are also free to enrol at a Medical Health Centre (MHC, maison médicale in French) of their choice. MHCs operate an alternative health care model, bringing together first-line care workers (general practitioners, nurses, physiotherapists, psychologists,

2 - http://www.riziv.fgov.be/fr/themes/cout-remboursement/facilite-financiere/Pages/tiers-payant.aspx\#.Waq8YchJY2w (accessed on 20 January 2020). 
social workers, etc.) into multidisciplinary teams. They work in concert in order to care for their patients and enhance or maintain their social welfare. Importantly, most Belgian MHCs have recourse to an alternative funding model that relies on capitation payments for first-line medical acts (general medicine, physiotherapy, nursing care), ${ }^{3}$ in contrast to the prevailing feefor-service model. ${ }^{4}$ The most recent figures available show that in 2015 , the number of MHCs amounted to $151,{ }^{5}$ compared to 67 in 2005. Furthermore, 3\% (336,247 patients) of the Belgian population was affiliated with an $\mathrm{MHC}$ in $2015 .^{6}$

\section{A joint plan}

Belgium is a federal state made up of a federal government and federate entities with their own competencies, i.e., three economic regions (the Flemish, Walloon and Brussels-capital regions) and three linguistic communities (the Flemish Community, the French Community, also called the Wallonia-Brussels Federation, and the German-speaking Community), which use the three official languages: Dutch, French and German. This structure is the result of an ongoing process of federalisation and devolution that began in 1970. Following the Sixth State Reform, the second step of which occurred in 2014, public health competencies were redistributed and mainly split between the federal and regional levels, which explains why there are several health ministers in Belgium (see Appendix 1 summarising the distribution of health competencies in Belgium). The IC4BH plan was originally initiated at the federal level, but the federal authorities intended to develop some elements that are now under the competence of the regions, which explains why the IC4BH plan is a joint plan.

\section{Methods}

This inductive ethnographic study began in December 2016. Ethnography, also referred to as field research, is a holistic discovery-based and hypothesis-free research method emanating from the social sciences (Robinson, 2013), more specifically, from anthropology and sociology (Soukup et al., 2017). In this approach, people and groups are studied in their real-world settings, in other words, "mundane settings in which people lead their lives naturally and that are not designed for the purposes of research" (Maner, 2016, p. 101), such as schools, homes, the workplace, hospitals, meetings, court rooms, etc. (Maner, 2016; Soukup et al., 2017). Accordingly, ethnographic studies distinguish themselves from experimental ones, which are conducted in simulated or controlled environments (Angrosino, 2007; Soukup et al., 2017).

Field research is characterised by the combination of several complementary research methods (observation, interviews, secondary data analysis), allowing a deep and detailed understanding of a setting, a context and/or a phenomenon (Quivy \& Campenhoudt, 2009), which is why it seemed relevant to study the integrated care pilot projects' dynamics depending on interactions between stakeholders. This type of research is inherently flexible and non-linear given that no definitive research protocol is determined at the beginning of the research, but rather is expected to evolve during the research (Quivy \& Campenhoudt, 2009). This approach has its limitations: conducting field work is time consuming and the findings are often not generalisable (Soukup et al., 2017). However, as Flyvbjerg (2006) puts it, the fact that, "knowledge can-

\footnotetext{
3 - http://www.riziv.fgov.be/fr/themes/cout-remboursement/par-mutualite/maison-medicale/Pages/default.aspx\#. WapxpMhJY2w (accessed on 20 January 2020)

4 - http://www.maisonmedicale.org/En-quelques-mots.html (accessed on 20 January 2020)

$5 \quad-\quad$ http://www.lejournaldumedecin.com/actualite/plus-de-150-maisons-medicales-en-belgique/article-normal-22247.html (accessed on 20 January 2020)

6 - http://www.dhnet.be/actu/belgique/la-belgique-compte-plus-de-150-maisons-medicales-579f96fc35705dcbd70cf3a2 (accessed on 20 January 2020)
} 
not be formally generalized does not mean that it cannot enter into the collective process of knowledge accumulation in a given field or in a society" (Flyvbjerg, 2006, p. 227).

As part of her specific ethnographic research, which took the form of a qualitative and inductive (Musselin, 2005) research, the researcher immersed herself mainly in two pilot projects. The data were collected during the conceptualisation phase, i.e., the application writing period, as well as during the first nine months of the execution phase, during which the pilot project consortia began to implement the loco-regional action plan they conceived during the conceptualisation phase.

According to Dumez (2016), "a qualitative research approach only makes sense if it shows and analyses the intentions, the discourse and the actions and interactions of the actors, both from their point of view and from the researcher's point of view" (Dumez, 2016, p. 13). To ensure the soundness of the analysis (Dumez, 2016), and achieve a sound level of saturation (Bryant \& Charmaz, 2011), three types of information sources were triangulated:

- written documents, through a literature review and the reading of operational documents;

- actions and interactions: the direct observation method was used in which the researcher attended 67 meetings, corresponding to 148 hours of observation; and

- discourses, referring to what people had to say about their experience, during semi-structured interviews $(\mathrm{N}=24)$.

Indeed, triangulation of information (Dumez, 2016; Jick, 1979) helps establish validity and reliability regarding the studied phenomenon (Robinson, 2013). Appendix 2 presents a thorough description of the methods combined to collect the data.

\section{Findings}

\section{Towards integrated care: opting for pilot projects}

At the international level, integrated care is considered to be a relevant solution to deal with care fragmentation (Minkman, 2017) and tackle the challenge of long-term care patients (Borgermans \& Devroey, 2017). Nevertheless, it can take a variety of forms depending on the context in which it is implemented (Borgermans et al., 2017). There is no consensus on one single and universal definition of this concept due to its polymorphous nature (Amelung et al., 2017). In the IC4BH plan, integrated care delivery is defined as, "the management and delivery of health services so that clients receive a continuum of preventive and curative services, according to their needs over time and across different levels of the health system" (WHO, 2008b, p. 1). Further, the World Health Organization (WHO) defines care integration as, "the organization and management of health services so that people get the care they need, when they need it, in ways that are user friendly, achieve the desired results and provide value for money" (WHO, 2008a, p. 1).

National institutional arrangements and culture have a significant influence on how innovative solutions are translated at the local level (Marmor et al., 2005). Health care systems result from specific building processes deeply linked to their history, traditions and national contexts (Minkman, 2017), which give them their "own individual equilibrium" (Schokkaert \& Van de Voorde, 2011, p. 7). Transferring isolated policy measures from one country to another, without considering the context in which they will be implemented, can be fruitless or even risky (Schokkaert \& Van de Voorde, 2011). Therefore, the Belgian authorities mobilised field workers, connoisseurs of the Belgian-specific context, as part of an iterative and incremental 
implementation through pilot projects, the idea of co-creation being the guiding thread of the process.

Indeed, other implementation methods could have been used. As an example, the authorities could have passed a law after having negotiated the reform, as usual, in the decision-making organs of the NIHDI, two of the most important ones being:

- the "General Council of the Health Insurance", which gathers employers' representatives, workers' representatives, government's representatives and insurers' representatives (healthcare mutuals);

- the "Health Insurance Comity", which gathers insurers' representatives and healthcare providers' representatives (INAMI, 2019).

However, the authorities opted for another way of proceeding, as already explained. Why, then, were workers mobilised in the field specifically through pilot projects? Here are some of the reasons explaining this choice that were mentioned during the interviews:

We discovered the international reference framework [of integrated care], which was not very well known in our country, to help us put in place a real action plan by choosing to embark on a bottom-up approach. And we had good reasons, because we knew very well that trying to fundamentally change the way care is organised, if we want to do it in a [traditional] concerted way, we will never reach a national consensus; it's impossible. We are not going to get all the medical unions and all the hospital networks and everyone to agree ... Oh yes, yes, we are going to change. That's not how it works. So, the only way, the idea, and I still believe in it, is that we can change things through a bottom-up approach. If we do it in a sufficiently substantial and global manner [...], it is much better supported by [specific] needs or by a way of demonstrating that we succeeded in shifting the paradigm. This is change management, but by looking for the avant-garde in it. (Interview with a high-ranking official, 2017)

Pilot projects are [...] less frightening than a change of law, regulation or financing mode. (Interview with a high-ranking official, 2017)

The important thing is really to set up a methodology so that all things are taken into account, and that it is also sufficiently participatory because the element of cocreation is really essential for me in this project, and I often stress this. Sometimes, more than the result to be achieved, it's the whole method to get there that is very important, the involvement of all the actors. (Interview with a coach, 2017)

In these extracts, the interviewees expressed the advantages and the reasons that led to the choice of pilot projects as implementation instruments. The first interviewee explained that the traditional way of making decisions, at the level of the NIHDI bodies, would simply have hindered finding an agreement on how to implement integrated care due to the diverging interests of the represented sectors. Such an agreement would, nevertheless, have been a prerequisite to any legal text intended to bring about structural changes in the way of working in the care sector. Therefore, the use of pilot projects was a way around this problem. The purpose was to show that some projects would succeed in implementing integrated care in their geographic area, hopefully serve as successful examples and produce a snowball effect in the areas in which no integrated care projects were implemented. The second interviewee stressed that the actions undertaken at a small scale, at the pilot project level, should be less frightening for hands-on professionals because they are more reversible than those that would have been directly implemented on a large scale to comply with the law. Finally, the third interviewee un- 
derlined the importance of working in co-creation with hands-on professionals. Professionals should be able to produce innovative propositions anchored in their day-to-day reality, including contextual elements that the authorities would not have considered.

\section{Integrated care pilot projects}

At the federal level, the inter-administrative cell (IAC) was created pursuant to the Protocol of Understanding of the Inter-ministerial Conference of the 24th February, 2014 regarding the health policy for chronic patients. The IAC was assigned the role to manage and coordinate the operational implementation of the plan, and to help, guide and collaborate with the pilot projects as part of the iterative and incremental co-creation dynamic. This department gathered public officials of the NIHDI and of the Federal Public Service (FPS) Public Health. They also worked in close collaboration with representatives of the federal health minister's office (Belgian Ministry of Social Affairs and Public Health, 2015).

Figure 1 - The inter-administrative cell

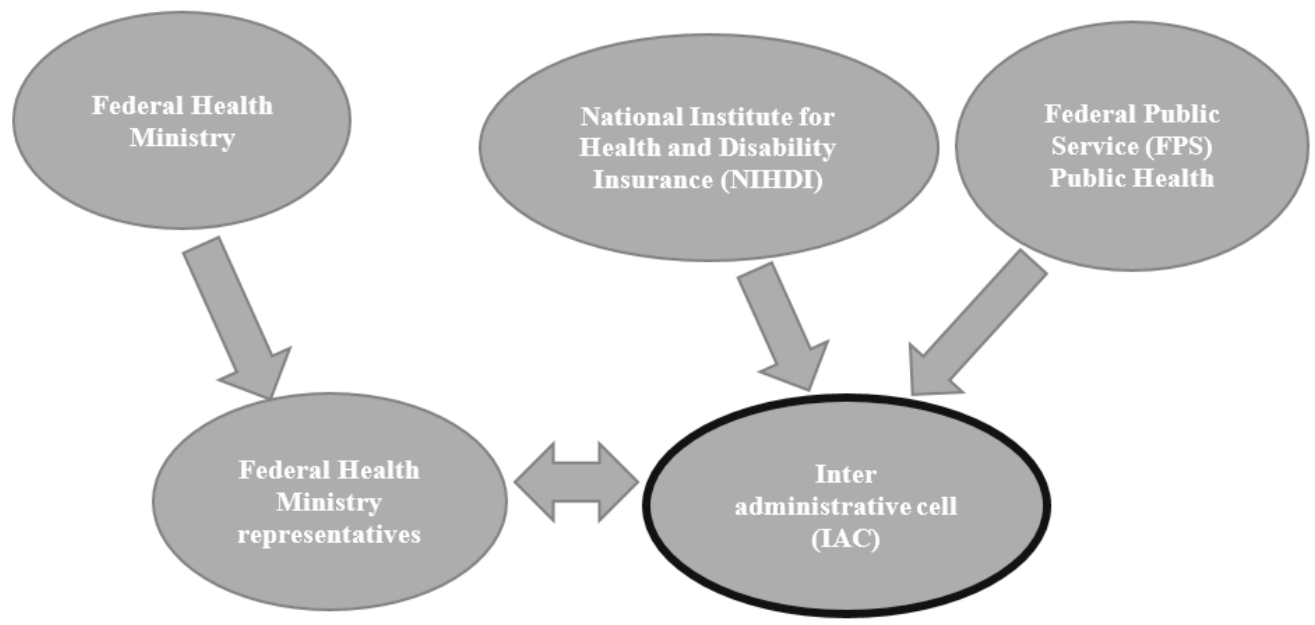

Source: The Author

In January 2016, the Belgian health authorities published a guidance leaflet for future pilot projects in which they described the specific modalities of the implementation process. This leaflet specifically stated that it was meant to be evolutionary: the modalities were meant to be modified, if necessary, and new guidelines could be articulated by the authorities in the future, depending on the turn of events. This relates to the willingness of iterative and incremental co-creation expressed by the authorities in the plan.

The implementation process was divided into four main phases (Belgian Ministry of Social Affairs and Public Health, 2015):

1. The preparation phase (first phase of the selection procedure): the four-month preparation phase began in February 2016, when the authorities launched a call for expressions of interest. Hands-on professionals, interested in creating a pilot project, had to gather in multidisciplinary local consortia. They had to submit a joint expression of interest defining, approximately, their target groups, as well as the geographic area covered by their projects, by 31st May, 2016.

2. The conceptualisation phase (second phase of the selection procedure): between July 
2016 and September 2017, the 20 selected pilot project consortia had to write a more detailed application file containing a 'loco-regional action plan'. This plan needed to describe their common vision and their strategic and operational objectives, as well as the actions they would implement to achieve their objectives if they were selected for the four-year execution stage. As from this phase, each consortium had to appoint a local coordinator whose remit was to lead the process of creating the loco-regional action plan. The local coordinator was the main point of contact between the project and the authorities. During this phase, a lump sum funding of 40,000 euros, payable in two instalments, was provided to pay the coordinator's salary.

3. The execution phase: in January 2018, the twelve selected pilot projects entered the four-year execution phase and began to implement their loco-regional action plan.

4. The expansion phase: after the execution phase, the successful pilot projects were expected to evolve to cover the entire Belgian population.

It is clear that the two first phases were dedicated to designing the experiments that would be carried out in the field during the third phase. The third phase was actually both an implementation and experimentation phase. The expansion phase is intended to implement actions identified as best practices at a wider scale.

\section{A continuous co-construction process}

Achieving co-creation required regular contacts between the parties involved. During the preparation and the conceptualisation phases, several meetings ("kick off meetings", information and plenary sessions and "intervisions") bringing together the IAC members, some representatives of the federal health minister's office, the coordinators and some pilot project members were organised to this end. The first three types of meetings were more formal and less regular than the intervisions, which were organised on a monthly basis.

Intervisions were key moments of discussion between the authorities, the coordinators and the pilot projects' key stakeholders who accompanied them. The authorities gave presentations on specific topics, provided additional instructions and new guidelines and answered coordinators' questions. The coordinators also had the opportunity to relay the difficulties, fears, disagreements and requests of their respective pilot project consortium and ask for clarification regarding some elements or procedures. They also communicated with their peers and discussed their respective practices.

Figure 2 - Stakeholders' interaction during intervisions 

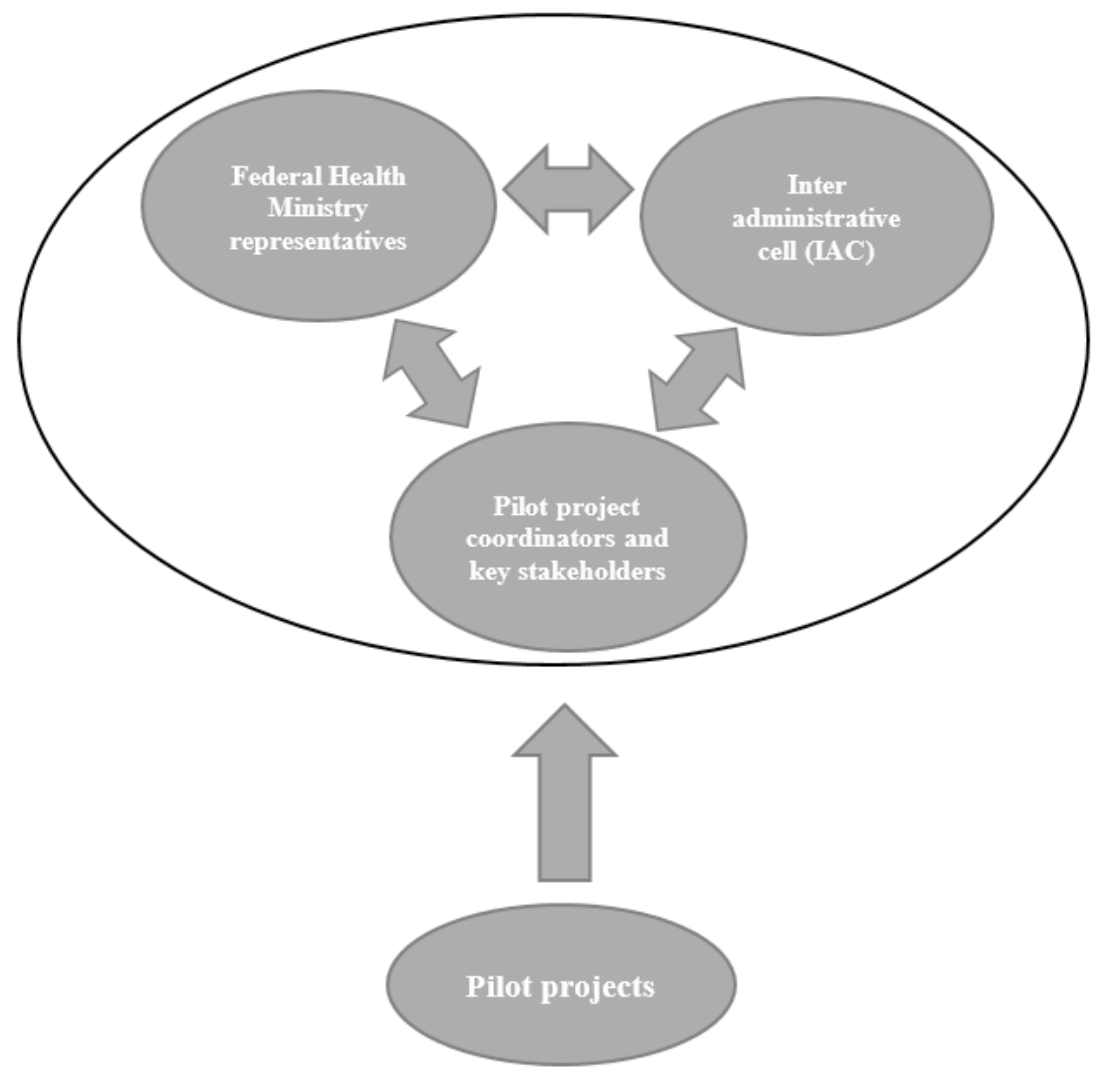

\section{Source: The Author}

Intervisions were not often peaceful due to the frequent divergence of opinion regarding several matters between the authorities and the pilot project members, whose opinions were relayed by the coordinators. For instance, one disagreement pertained to financial aspects and, more precisely, to the notion of 'bundled payment'.

Actually, in July 2011, the Belgian Health Care Knowledge Centre (KCE), a research centre that provides scientific advice on topics related to health care, was asked to produce a position paper related to future health care for chronic diseases. This scientific report, published in December 2012, summarised the challenges in this field through eighteen integrated care components (see Appendix 3), based on a consultation with experts and a thorough international literature study regarding integrated care (Belgian Ministry of Social Affairs and Public Health, 2015). The IC4BH plan is an attempt to put into practice these recommendations.

One of the $20 \mathrm{KCE}$ recommendations, which became the 12th of the 20 components of the IC4BH plan, referred to the adaptation of financing systems. As a reminder, the majority of physicians are self-employed and remunerated on a fee-for-service basis; however, the federal authorities expressed their intention to move from a fee-for-service system to a bundled payment model, at least for certain types of medical services, justifying their choice by reference to the international scientific literature regarding this topic.

In this literature, one can read that fee-for-service rewards volume instead of quality of care 
(Borgermans \& Devroey, 2017; Hirsch et al., 2015) and can therefore hinder the implementation of integrated care based on a global patient-centred approach. A bundled payment system would seem more appropriate according to the scientific literature (Quinn et al., 2017). Bundled payment actually refers to, "a fixed payment that includes the prices of a group of services that would typically treat an episode of care in a defined period of time" (Quinn et al., 2017, p. 114). Using bundled payments could help neutralise expenses, enhance value of care and, consequently, enhance the system's sustainability at the macro-level.

As a result, during the conceptualisation phase, the authorities encouraged the pre-project consortia to include actions in their loco-regional action plans that would help develop and test bundled payment at the local project scale. However, professionals in the field quickly opposed this request for several reasons, which surprised the authorities given all the advantages of this payment model identified in the literature.

In an atmosphere of mistrust and suspicion, professionals argued that the concrete implementation modalities of such a transition were not clear enough. They did not have sufficient guarantees of support from the authorities to achieve this economic transition. Here is an interview extract illustrating this idea: "It is like buying a car. But, when you drive it, you realise that they are still building the car while you are driving it and you cannot get out of it anymore." (Interview with a coordinator, 2017).

Furthermore, this would require a huge cultural change at every level of the Belgian care production chain. They stressed that the authorities wanted to impose things and put the cart before the horse regarding this matter, arguing that Belgium is not yet ready for bundled payments: "I cannot prevent myself from thinking that it is pretending to be bottom-up and is really top-down. They are going to compel us to work in a certain way." (Interview with a pilot project member, 2016).

While this choice is understandable at the macro level given that it could help reduce health expenditure, at the micro level, the professionals were worried, particularly the doctors, because their remuneration mode and their income would probably be impacted. As such, what would be a saving for the government would be a loss of income for medical professionals. Indeed, bundled payment transfers the risk from payers to providers, sometimes even resulting in financial losses for the latter (Quinn et al., 2017). Some GPs even threatened to leave their respective projects, which would have simply prevented the other stakeholders from submitting the application at the end of the conceptualisation phase: GPs were, indeed, mandatory project members.

At the request of those in the field (not only GPs), several additional meetings were set up to discuss the matter. This, among other factors, contributed to lengthening the conceptualisation phase, which was supposed to finish at the end of January 2017, but which actually ended mid-September 2017. Both parties tried to convince the other of the validity of their vision based on different types of arguments, i.e., scientific- (authorities) or experience-based (field workers). In the end, despite the authorities' insistence, no project complied with the request of designing actions to test actual bundled payment during the execution phase. Actually,

[the authorities] adapt, they are open to discussion with the projects but in this case, they [simply] had no choice. [They] felt that if GPs blocked the integrated care pilot projects, there would not be any integrated care pilot project anymore. [Dealing with] chronic diseases without GPs is not feasible. (Interview with a pilot project coordinator, 2018) 
This empirical example illustrates the strong interdependence between the different hierarchical levels of the health care system. Here are some other interview excerpts confirming this assertion:

Obviously, the powerful argument of pilot project professionals is to say: 'anyway, without us, what do you want to do? If no one wants to participate in your pilot projects, what are you [the authorities] going to do?' (Interview with a pilot project member, 2018)

Could they compel [us to do what they want us to do]? No [...], but what is the alternative? If we [hands-on professionals] do not comply voluntarily, we may be compelled. That is the threat. [The authorities could say]: 'if you do not want it, then, we will see if we cannot pass a Royal Decree'. (Interview with a pilot project member, 2018)

Change is frightening. [...] We [the authorities] know that there is a lot to do in the field. It is for this reason that it seems essential to take action at several levels and with hands-on professionals, because we cannot impose change alone. We can write a Royal Decree but ... (Interview with a high-ranking official, 2017)

If we want to change things, dialogue [is a compulsory step]. (Interview with a pilot project member, 2018), people from all the levels have to gather and negotiate.

\section{Discussion}

In an explorative context, workers in the field were delegated the task to both design and test new actions intended, if successful and identified as best practices, to develop integrated care for chronic patients on a national scale. The Belgian authorities chose to use pilot projects and mobilise hands-on professionals' experience and expertise:

- to avoid the problems that the traditional way of doing things could have caused;

- due to the contextual nature of integrated care (Amelung et al., 2017; Minkman, 2020) and the resulting lack of knowledge regarding the way integrated care could/should be implemented in the Belgian context; and also

- to benefit from the professional experience of field workers.

In the literature on policy making and policy design, this "co-creation" approach relates to the notions of "collaborative innovation" (Torfing, 2019, p. 4) and "process inclusivity" (Compton et al., 2019, p. 124), which both refer to the degree to which diverse interests are represented in the decision-making process, inter alia those of the directly affected stakeholders.

Including the latter in decision-making is considered desirable for several reasons. Given their experience and proximity with the field, they are expected to know the local context better, allowing them to produce tailored solutions and, as a result, solutions that are supposedly better. Furthermore, bottom-up collaboration between these stakeholders is also viewed as an advantage enhancing the legitimacy of the policy and helping build trust. Eventually, given that they will have a role to play in the implementation of the decisions made (Compton et al., 2019; Lee, 1999), it is also expected to enhance the acceptance of these decisions (Vreugdenhil \& Ker Rault, 2010).

In the context of the IC4BH plan, the use of pilot projects was a way to achieve inclusivity by including workers in the field in the process and work of "co-creation" to benefit from their 
respective experience (Gouillart \& Hallett, 2015). Nevertheless, if this inclusive co-creation approach leading to multi-actor collaboration (Torfing, 2019) may be seen as a key facilitating factor (Compton et al., 2019), especially in a context of innovation (Torfing, 2019), an important lesson to draw from this research is that this alone does not guarantee the achievement of the desired outcome or that events unfold as planned. This research actually suggests that it also brought with it new issues to address, as detailed below.

\section{New collaboration modalities}

The co-creation approach called for regular meetings between the different stakeholders, creating new collaboration modalities. The meetings of the IAC members, representatives of the federal health minister's office, the coordinators and key pilot project members, i.e., GPs, nurses, social workers, etc., contributed to progressively create a new dynamic of vertical interactions and vertical communication between stakeholders at the macro and the meso levels and, in this way, to alleviate the vertical organisational fragmentation between these levels. Gathering these different types of people on a regular basis is quite unusual in Belgium. As already mentioned above, health matters are normally discussed in the decision-making organs of the NIHDI, in which all the sectors involved in the pilot projects are not represented.

These specific meetings, which were particularly crucial throughout the process, had a goal to sustain the iterative and incremental co-creation process by providing the coordinators with support for the needs they had expressed. While these meetings were initially meant to be mostly informative, the participants appropriated the encounters, viewing them as a venue for expression, as opportunities to negotiate their participation in the projects or even call into question the content of the authorities' guidelines, which surprised the authorities.

The IC4BH plan is the result of a long reflection process in which, "knowledge [played] a fundamental justification function" (Radaelli, 1995, p. 174): the guidelines were built on the basis of scientific expertise on integrated care. Indeed, several Belgian public officials and policymakers took a closer look at successful cases of integrated care abroad; they attended scientific conferences abroad on the topic and relied on the KCE position paper.

Accordingly, "The relationship between expertise and politics has traditionally been described in terms of science speaking truth to power" (Pellizzoni, 2011, p. 765). Nevertheless, the recommendations and the guidelines designed by the authorities did not always seem relevant to the pilot projects' stakeholders, as shown in the empirical example above pertaining to bundle payments. Their diverging opinions led to a cultural clash (Moran \& Rau, 2016) and heated negotiations to deal with the controversy (Callon, 1984). Hands-on professionals openly questioned and negotiated the authorities' guidelines built on scientific expertise, the legitimacy of which they put into question by justifying their opinion on the strength of their place-based knowledge of the health care system at the local level (Moran \& Rau, 2016) related to their practice and their experience (Wagenaar \& Cook, 2011).

This example illustrates that, "instruments at work are not neutral devices: they produce specific effects, independently of the objective pursued (the aims ascribed to them), which structure public policy according to their own logic" (Lascoumes \& Le Gales, 2007, p. 3). Indeed, the use of pilot projects in a context of co-creation allowed their members to question and renegotiate the framework set by the authorities, which the latter did not expect. Pilot project stakeholders took advantage of these moments of interaction to define, clarify or redefine their respective roles and responsibilities. They sometimes even refused to achieve what was expected of them, arguing that the authorities were imposing autocratic top-down measures 
(O’Riordan et al., 2015) based on de-contextualised scientific knowledge (Moran \& Rau, 2016), which was irrelevant in the Belgian-specific context. Not all of this would have been possible if the authorities had passed a law to implement the IC4BH plan. In this case, hands-on professionals would have been considered passive implementers who would have had to comply with the law, under the pain of sanctions.

In the case of integrated care pilot projects, implementers (pilot project stakeholders) were involved in a decision-making process at the local level: they were responsible for building and implementing their own loco-regional action plans. They were supposed to be active and to be involved voluntarily in the co-creation process initiated by the authorities, which they were, but not always in the manner expected by the latter, as illustrated in the example of bundled payments. This situation gave power to pilot project stakeholders who had the opportunity to influence the course of events, bringing significant unpredictability to the process.

Indeed, the result of local people's reflections was often different from the authorities' expectations and wishes. They were able to question everything and even leave the process at any time without sanction if they chose to do so, something the authorities feared given that they were depending on them to implement integrated care in Belgium. On the other hand, the local professionals feared that the authorities might pass a law to impose their framework without taking their opinion into account if they left the process, which explains why, even if some stakeholders threatened to give up and leave the process, few actually carried out this threat. Through their regular interactions, IAC members, health ministry representatives, as well as pilot project coordinators and key stakeholders (see Figure 2) transformed the IC4BH plan implementation modalities. In this way, they transformed the public policy itself, creating a tripartite, "crossed-regulation" (Crozier \& Thoenig, 1975). This means that each of the three parties involved was regulating the others and was also regulated by them in return: they were actually interdependent (Crozier \& Thoenig, 1975, p. 12) and each held power.

Eventually, a serendipitous observation lies in the fact this process was neither completely bottom-up, as the authorities argued, nor entirely top-down, as several pilot project stakeholders put it. The authorities set the initial framework for action and determined the general aim, i.e., the metaproject (Lascoumes \& Le Galès, 2005) (implementing integrated care), which was non-negotiable. They articulated guidelines and took the initiative to launch the call for pilot projects to materialise this metaproject. This gave pilot project members the impression that the process, which was supposed to be bottom-up, was actually disguised top-down, and that this was not "real co-creation". Nevertheless, as explained in the example above, pilot project stakeholders actually did have the opportunity to make proposals, negotiate things and influence the unfolding implementation process. Accordingly, if this was not co-creation, as pilot project stakeholders put it, it was at least a process punctuated by constant interactions, discussions and negotiations, probably inherent in iterative and incremental innovation. Therefore, in general, the achieved result would never be completely what the authorities or the pilot project stakeholders anticipated, but would rather be the outcome of successive mutual adjustments between them (Lascoumes \& Le Galès, 2005).

\section{Becoming representatives}

According to Lascoumes and Le Galès (2007), "Every instrument constitutes a condensed form of knowledge about social control and ways of exercising it" (Lascoumes \& Le Gales, 2007, p. 3). Using pilot projects to implement the plan has been reshaping, "the relationship between the governing [the usual decision-makers] and the governed [the usual implementers]" (Las- 
coumes \& Le Galès, 2007, p. 7) and has had consequences in terms of citizenship. It has begun to blur the lines between these two statuses, creating a new intermediary local level at which people gather to design joint projects and make important decisions.

Indeed, pilot project stakeholders (corresponding to the governed in Lascoumes and Le Galès's framework) have been increasingly involved in the decision-making process. They have acquired a certain capacity for influencing things and questioning the authorities' framework by acting as representatives of their profession and of their project, a role to which they were not accustomed. Progressively, they have learned to assume this new role by taking part in pilot projects, exchanging ideas, and defending their interests and opinions. On the other hand, those at the macro level were put in a position in which they had to listen to the field workers' demands and consider them in order to orient their future decisions and provide them with support.

As a result, one can argue that the use of pilot projects supported the development of a "negotiated governance" (Lascoumes \& Le Galès, 2005, p. 23). This observation denotes a transition from a social guardian state, which commands and controls, towards a mobilising state (Lascoumes \& Le Galès, 2007), which sets the general framework for action, provides general direction, mobilises local people by delegating some tasks to them, and lets them take concrete action to achieve the general aim, in this case achieving integrated care in Belgium.

\section{An uncomfortable and risky endeavour}

In an iterative regime of innovation involving constant confrontation of opinions, the project approach generates discomfort, immersing stakeholders at every level in a climate of (sometimes huge) uncertainty. Setbacks and changes of direction are frequent, which provokes anxiety and fatigue. As Segrestin (2004, p. 244) puts it, "they have embarked on projects as one would have on a risky expedition", betting on the future without completely knowing what would be asked of them and to what this would actually lead, such as, for example, bundled payments.

Except for the coordinators, no additional human resources were financed: pilot project members took part voluntarily in pilot project meetings as representatives on a regular basis. This additional task required massive time investment, making their workload heavier and heavier and reducing the amount of time left to achieve their other tasks, for which some receive subsidies from the Belgian federate entities. This created a situation in which they had to deal with several workloads (and sometime incompatible guidelines) attributed by different levels of power (federal level, federate entities).

As a result, field workers were put under pressure to take innovative initiatives, but had simultaneously to deal with many constraints (institutional, financial, organisational, legal, etc.), which reduced their flexibility. Incidentally, some interviewees stressed the psychological costs related to the process due to the heavy workload and the constant uncertainty inherent in the project's approach.

\section{Conclusion}

This paper addressed the following research question: how does the use of multidisciplinary pilot projects as experimentation and implementation instruments reshape modes of public governance in the Belgian health sector in a context of transition and ongoing devolution? Actually, the use of pilot projects was a way to include workers in the field in the process in order to work in "co-creation" to benefit from their respective experience, and in this way achieve 
process inclusivity. If process inclusivity is recognised in the scientific literature as a success factor, this research suggests that it is also important not to view it as something "magical" that alone can erase all uncertainties or guarantee the peaceful implementation of a policy. Instead, it also brings with it new issues and controversies to address.

Indeed, one could have imagined, for example, that this new inclusive way of working would have resulted in a simple and peaceful transfer of tasks to the members of the pilot projects, the main task delegated being the design of innovative concrete actions to implement integrated care in Belgium. Instead, it seems that the use of pilot projects was progressively reshaping modes of public governance by transforming the roles of both the authorities and the actors involved in such projects, which were new roles that had to be learnt. The new authorities 'role was to offer support, which, in this case, led to the creation of a new department, the IAC, dedicated to this support mission. On the other hand, pilot projects stakeholders still shouldered the role of implementers as they would have traditionally; however, in this scenario, they had to implement actions that they themselves had designed, not actions designed by the authorities in collaboration with scientific experts. As such, in a certain way, they were both implementers and decisions-makers given that they had to make decisions about what should be done in the field. Therefore, the use of pilot projects, with an initial purpose of experimentation and implementation, also led to blurring the line between the roles of decision-maker and implementer.

Importantly, this role transformation required new modalities of collaboration between the authorities and pilot project consortia. It led to the emergence of new practices: regular meetings between people who usually did not meet. Indeed, the iterative and incremental transition towards integrated care required that the authorities and local professionals collaborate closely. To that end, they met on a regular basis, notably during monthly intervisions. This led to building bridges between the different levels of the care production chain, notably between ministry representatives, public officials (IAC members) and pilot project stakeholders, resulting in the emergence of vertical collaboration, and one can even suggest the emergence of the early stages of an organisational vertical integration (Axelsson \& Axelsson, 2006). In this context, the local professionals progressively learned to assume the new role of representatives of their project and profession, which is symptomatic of a more negotiated governance (Lascoumes \& Le Galès, 2005).

Nevertheless, given that these different stakeholders each had their own logic of action (expertise-based vs. practice-based), some unexpected controversies emerged during the process, e.g., regarding financial aspects. This example shows that pilot project members succeeded in influencing the process and calling into question the framework set by the authorities, which the latter did not expect. Accordingly, they all entered a non-linear and sometimes conflictual process of constant interactions, discussions, negotiations and successive mutual adjustments as part of a tripartite crossed-regulation (Crozier \& Thoenig, 1975), symptomatic of process inclusivity concretely put into practice.

The lesson to be drawn here is that interacting is a first, but not a sufficient, step to achieve real co-creation, which should result in vertical integration. Real co-creation requires that all stakeholders, regardless of their position in the care production chain (so, policy-makers included), interact regularly and expect controversies or even cultural clashes to emerge. Overcoming these differences of opinion involves making the effort to stand in the shoes of others to understand their respective day-to-day realities by really listening to what they have to say, which does not seem to be a natural practice at present. The research therefore underlines that 
the project approach also has its limitations: the additional workload, the inherent constant (sometimes conflictual) confrontation of opinions and changes of direction creating an uncomfortable climate of uncertainty, all of which raise questions in terms of well-being at work.

In conclusion, the results of this research might be of interest to policy makers who wish to use pilot projects to test and implement policies, in the health sector but also in other sectors. Nevertheless, further research is needed to establish the generalisability of the findings presented in this paper regarding the pilot project phenomenon. They should be put into perspective with the results of other research, such as, for example, similar research focusing on other pilot projects, both in Belgium and abroad, in the health sector or even in sectors such as education, employment and social action, among others. This would help identify what is specific for each sector regarding the use of pilot projects and what are common characteristics of the instrument pilot project, whatever the sector in which it is used.

\section{Bibliography}

Ali, M. (2013). Assessment of Policy Instruments. In Sustainability Assessment (pp. 99-106). Elsevier. https://doi.org/10.1016/B978-0-12-407196-4.00008-8

Amelung, V., Stein, V., Goodwin, N., Balicer, R., Nolte, E., \& Suter, E. (Eds.). (2017). Handbook Integrated Care. Springer International Publishing.

https://doi.org/10.1007/978-3-319-56103-5

Angrosino, M. (2007). Doing Ethnographic and Observational Research. SAGE Publications Ltd. https://doi.org/10.4135/9781849208932

Axelsson, R., \& Axelsson, S. B. (2006). Integration and collaboration in public health-A conceptual framework. The International Journal of Health Planning and Management, 21(1), 7588. https://doi.org/10.1002/hpm.826

Belgian Ministry of Social Affairs and Public Health. (2015). Plan conjoint en faveur des malades chroniques: "Des soins intégrés pour une meilleure santé ».

Retrieved from: http://www.integreo.be/sites/default/files/public/content/plan_fr.pdf

Borgermans, L., \& Devroey, D. (2017). A Policy Guide on Integrated Care (PGIC): Lessons Learned from EU Project INTEGRATE and Beyond. International Journal of Integrated Care, 17(4). https://doi.org/10.5334/ijic.3295

Borgermans,L., Marchal, Y., Busetto,L., Kalseth, J., Kasteng,F., Suija, K., Oona, M., Tigova, O., Rösenmuller, M., \& Devroey, D. (2017). How to Improve Integrated Care for People with Chronic Conditions: Key Findings from EU FP-7 Project INTEGRATE and Beyond. International Journal of Integrated Care, 17(4). https://doi.org/10.5334/ijic.3096

Borrás, S., \& Edquist, C. (2019). Holistic innovation policy: Theoretical foundations, policy problems, and instrument choices . Oxford: Oxford University Press.

Bryant, A., \& Charmaz, K. (Eds.). (2011). The SAGE handbook of grounded theory (Paperback ed., reprinted). Sage Publications.

Callon, M. (1984). Some Elements of a Sociology of Translation: Domestication of the Scallops and the Fishermen of St Brieuc Bay. The Sociological Review, 32(1_suppl), 196-233. https://doi.org/10.1111/j.1467-954X.1984.tb00113.x 
Capano, G., Pritoni, A., \& Vicentini, G. (2020). Do policy instruments matter? Governments' choice of policymixandhighereducationperformanceinWesternEurope.JournalofPublicPolicy, 40(3), 375-401. https://doi.org/10.1017/S0143814X19000047

Compton, M. E., Luetjens, J., \& Hart, P. (2019). Designing for Policy Success. International Review of Public Policy, 1(2), 119-146.

https://doi.org/10.4000/irpp.514

Crozier, M., \& Thoenig, J.-C. (1975). La régulation des systèmes organisés complexes: Le cas du système de décision politico-administratif local en France. Revue Française de Sociologie, 16(1), 3. https://doi.org/10.2307/3321128

De Block, M. (2017). Evaluation du tiers payant obligatoire: L'objectif est atteint, l'accessibilité des soins de santé augmente. Retrieved from:

https://www.deblock.belgium.be/fr/evaluation-du-tiers-payant-obligatoire-1\%E2\%80\%99objectifest-atteint-1\%E2\%80\%99accessibilit\%C3\%A9-des-soins-de-sant\%C3\%A9

Dumez, H. (2016). Méthodologie de la recherche qualitative: Les questions clés de la démarche compréhensive. Retrieved from

http://sbiproxy.uqac.ca/login?url=https://international.scholarvox.com/book/88835027

Engström, S., \& Lidelöw, S. (2015). From the Pilot Project to the Mainstream Practice-Learning Explored in Planning and Design of a Low-Energy Quarter. Procedia Economics and Finance, 21, 288296. https://doi.org/10.1016/S2212-5671(15)00179-3

Federal Public Service Social Security. (2012). Social Security. Everything you have always wanted to know. Retrieved from:

https://socialsecurity.belgium.be/sites/default/files/alwa-en.pdf

Flyvbjerg, B. (2006). Five Misunderstandings About Case-Study Research. Qualitative Inquiry, 12(2), 219-245.

https://doi.org/10.1177/1077800405284363

Gouillart, F., \& Hallett, T. (2015). Co-creation in government. Stanford Social Innovation Review. Retrieved from: https://ssir.org/articles/entry/co_creation_in_government

Hassenteufel, P. (2011). Sociologie politique: L'action publique (2e édition). Paris: Armand Colin.

Hirsch, J. A., Leslie-Mazwi, T. M., Barr, R. M., McGinty, G., Nicola, G. N., Silva, E., \& Manchikanti, L. (2015). The Bundled Payments for Care Improvement Initiative. Journal of NeuroInterventional Surgery, 8(5), 547-548.

https://doi.org/10.1136/neurintsurg-2015-011746

Hood, C., Margetts, H., \& Hood, C. (2007). The tools of government in the digital age (New ed.). Palgrave Macmillan.

Howlett, M. (1991). Policy Instruments, Policy Styles, and Policy Implementation. National Approaches to Theories of Instrument Choice. Policy Studies Journal, 19(2), 1-21. https://doi.org/10.1111/j.1541-0072.1991.tb01878.x

Howlett, M. (2005). What is a policy instrument? Tools, mixes, and implementation style. In P. Eliadis, M. M Hill \& M. Howlett (Eds.), Designing Government: From Instruments to Governance (pp. 31-50). Montréal: McGill-Queen's University Press.

Howlett, M., Mukherjee, I., \& Woo, J. J. (2018). Thirty years of instrument research: What have we learned and where are we going? In H.K Colebatch \& R. Hoppe (Eds.), Handbook on Policy, Process and Governing Edward Elgar Publishing.

Retrieved from: https://ink.library.smu.edu.sg/soss_research/2762 
INAMI. (2019). Les organes du Service des soins de santé.

Retrieved from: https://www.inami.fgov.be/fr/inami/organes/Pages/soins-sante-organes.aspx\#Le_ Comit\%C3\%A9_de_1\%E2\%80\%99assurance_soins_de_sant\%C3\%A9

Jick, T. D. (1979). Mixing Qualitative and Quantitative Methods: Triangulation in Action. Administrative Science Quarterly, 24(4), 602-611.

Kay, A., \& Boxall, A. (2015). Success and Failure in Public Policy: Twin Imposters or Avenues for Reform? Selected Evidence from 40 Years of Health-care Reform in Australia*: Success and Failure in Public Policy. Australian Journal of Public Administration, 74(1), 33-41. https://doi.org/10.1111/1467-8500.12135

Lascoumes, P., \& Le Galès, P. (Eds.). (2005). Gouverner par les instruments. Paris: Sciences Po, Les Presses.

Lascoumes, P., \& Le Gales, P. (2007). Introduction: Understanding Public Policy through Its Instruments? From the Nature of Instruments to the Sociology of Public Policy Instrumentation. Governance, 20(1), 1-21.

https://doi.org/10.1111/j.1468-0491.2007.00342.x

Lee, K. N. (1999). Appraising adaptative management. Conservation Ecology, 3(2), 1-20.

Maner, J. K. (2016). Into the wild: Field research can increase both replicability and real-world impact. Journal of Experimental Social Psychology, 66, 100-106.

https://doi.org/10.1016/j.jesp.2015.09.018

Marmor, T., Freeman, R., \& Okma, K. (2005). Comparative Perspectives and Policy Learning in the World of Health Care. Journal of Comparative Policy Analysis: Research and Practice, 7(4), 331-348. https://doi.org/10.1080/13876980500319253

Minkman, M. (2017). Longing for Integrated Care: The Importance of Effective Governance. International Journal of Integrated Care, 17(4).

https://doi.org/10.5334/ijic.3510

Minkman, M. (2020). Suitable Scales; Rethinking Scale for Innovative Integrated Care Governance. International Journal of Integrated Care, 20(1).

https://doi.org/10.5334/ijic.5468

Moran, L., \& Rau, H. (2016). Mapping divergent concepts of sustainability: Lay knowledge, local practices and environmental governance. Local Environment, 21(3), 344-360.

https://doi.org/10.1080/13549839.2014.963838

Musselin, C. (2005). Sociologie de l'action organisée et analyse des politiques publiques: Deux approches pour un même objet? Revue française de science politique, 55(1), 51. https://doi.org/10.3917/rfsp.551.0051

OECD, \& European Observatory on Health Systems and Policies. (2017). Belgium: Country Health Profile 2017. OECD Publishing European Observatory on Health Systems and Policies. https://doi.org/10.1787/9789264283299-en

O’Riordan, M., Mahon, M., \& McDonagh, J. (2015). Power, Discourse and Participation in Nature Conflicts: The Case of Turf Cutters in the Governance of Ireland's Raised Bog Designations. Journal of Environmental Policy \& Planning, 17(1), 127-145.

https://doi.org/10.1080/1523908X.2014.914895

Palier, B. (2017). La réforme des systèmes de santé. Retrieved from:

http://ezproxy.usherbrooke.ca/login?url=https://www.cairn.info 
Pellizzoni, L. (2011). The politics of facts: Local environmental conflicts and expertise. Environmental Politics, 20(6), 765-785.

https://doi.org/10.1080/09644016.2011.617164

Pinson, G. (2005). Le projet urbain comme instrument d'action publique. In P. Lascoumes \& P. Le Galès (Eds.). Gouverner par les instruments (pp. 199-233). Paris: Sciences Po, Les Presses.

Quinn, A. E., Hodgkin, D., Perloff, J. N., Stewart, M. T., Brolin, M., Lane, N., \& Horgan, C. M. (2017). Design and impact of bundled payment for detox and follow-up care. Journal of Substance Abuse Treatment, 82, 113-121.

https://doi.org/10.1016/j.jsat.2017.09.012

Quivy, R., \& Campenhoudt, L. van. (2009). Manuel de recherche en sciences sociales. Malakoff: Dunod.

Radaelli, C. M. (1995). The role of knowledge in the policy process. Journal of European Public Policy, 2(2), 159-183.

https://doi.org/10.1080/13501769508406981

Robinson, S. G. (2013). The Relevancy of Ethnography to Nursing Research. Nursing Science Quarterly, 26(1), 14-19.

https://doi.org/10.1177/0894318412466742

Saltman, R. B., Busse, R., \& Figueras, J. (Eds.). (2004). Social health insurance systems in Western Europe. Maidenhead: Open Univ. Press.

Sanderson, I. (2002). Evaluation, Policy Learning and Evidence-Based Policy Making. Public Administration, 80(1), 1-22.

https://doi.org/10.1111/1467-9299.00292

Schokkaert, E., \& Van de Voorde, C. (2011). Belgium's healthcare system. Should the communities/ regions take it over? Or the sickness funds? Retrieved from:http://www.rethinkingbelgium.eu/rebelinitiative-ebooks/ebook-10-belgium-healthcare-system-communities-regions-take-over-sicknessfunds

Segrestin, D. (2004). Les chantiers du manager. Paris: Colin.

Service Public Federal Securité Sociale. (2016). La sécurité sociale. Tout ce que vous avez toujours voulu savoir. Retrieved from:

https://socialsecurity.belgium.be/sites/default/files/alwa-fr_1.pdf

Soukup, T., Lamb, B. W., Sevdalis, N., \& Green, J. S. (2017). Undertaking field research. Journal of Clinical Urology, 10(1), 58-61.

https://doi.org/10.1177/2051415816651562

Torfing, J. (2019). Collaborative innovation in the public sector: The argument. Public Management Review, 21(1), 1-11.

https://doi.org/10.1080/14719037.2018.1430248

Vabo, S. I., \& Røiseland, A. (2012). Conceptualizing the Tools of Government in Urban Network Governance. International Journal of Public Administration, 35(14), 934-946.

https://doi.org/10.1080/01900692.2012.691243

Vreugdenhil, H., \& Ker Rault, P. (2010). Pilot Projects for Evidence-Based Policy-Making: Three Pilot Projects in the Rhine Basin. German Policy Studies, 6(2) 115-151.

Vreugdenhil, H., Slinger, J., Thissen, W., \& Ker Rault, P. (2010). Pilot Projects in Water Management. Ecology and Society, 15(3).

https://doi.org/10.5751/ES-03357-150313 
Wagenaar, H., \& Cook, S. D. N. (2011). The push and pull of the world: How experience animates practice. Evidence \& Policy: A Journal of Research, Debate and Practice, 7(2), 193-212. https://doi.org/10.1332/174426411X579225

WHO. (2008a). Integrated health services- What and why?, Technical Brief No.1. May 2008.

Retrieved from: http://www.who.int/healthsystems/technical_brief_final.pdf

WHO. (2008b). Integrated health services- What and why? Technical Brief. №.1.2008.

Retrieved from: http://www.who.int/healthsystems/service_delivery_techbrief1.pdf

Zurlo, F., \& Nunes, V. dos G. A. (2016). Designing Pilot Projects as Boundary Objects. Springer International Publishing.

https://doi.org/10.1007/978-3-319-23141-9

\section{Appendix}

\section{Appendix 1 - Distribution of health competencies in Belgium}

\begin{tabular}{|l|l|}
\hline Belgian Federal State & $\begin{array}{l}\text { Flemish, Walloon and Brussels-capital } \\
\text { regions }\end{array}$ \\
\hline Managing the compulsory health insurance & Prevention and health promotion \\
\hline $\begin{array}{l}\text { Defining care professions as well as the re- } \\
\text { quired associated skills and qualifications }\end{array}$ & Organising front-line care and services \\
\hline $\begin{array}{l}\text { Setting medical fee standards for doctors, } \\
\text { nurses, midwives, physiotherapists, dieticians, } \\
\text { dentists, etc. }\end{array}$ & $\begin{array}{l}\text { Developing new instruments to support front- } \\
\text { line care providers, apart from that which is } \\
\text { related to health insurance matters }\end{array}$ \\
\hline $\begin{array}{l}\text { Defining and allocating admitted medical acts } \\
\text { between the different professions mentioned } \\
\text { above }\end{array}$ & $\begin{array}{l}\text { Financing general practitioners' associations } \\
\text { and defining the rules related to their govern- } \\
\text { ance }\end{array}$ \\
\hline Managing medical on-call services. & $\begin{array}{l}\text { Managing the multidisciplinary local net- } \\
\text { works, the integrated home care services, the } \\
\text { palliative care associations, the multidiscipli- } \\
\text { nary palliative teams and the "Impulseo fund", } \\
\text { which is a specific fund for general medicine } \\
\text { created to provide general practitioners with } \\
\text { financial help regarding their settlements }\end{array}$ \\
\hline
\end{tabular}




\section{Appendix 2 - Research Methods}

\section{Type of information source : written documents}

\begin{tabular}{|l|l|}
\hline $\begin{array}{l}\text { Data } \\
\text { collection } \\
\text { methods }\end{array}$ & Additional information \\
\hline $\begin{array}{l}\text { Literature } \\
\text { study } \\
\text { (scientific } \\
\text { literature) }\end{array}$ & $\begin{array}{l}\text { Aliterature study was conducted regarding the following topics: integrated } \\
\text { care, chronic diseases, pilot projects and public policy instruments. }\end{array}$ \\
\hline $\begin{array}{l}\text { Documentary } \\
\text { analysis } \\
\text { (political, legal } \\
\text { and } \\
\text { operational } \\
\text { documents) }\end{array}$ & $\begin{array}{l}\text { Several political, legal and operational documents were read, notably the } \\
\text { joint plan itself and the documents available on the website http://www. } \\
\text { integreo.be/fr/documentation. This website is a communication tool cre- } \\
\text { ated by the public authorities on which documents relating to the IC4BH } \\
\text { implementation plan were published, including political and legal docu- } \\
\text { ments, fact sheets, templates and application guidelines, and PowerPoint } \\
\text { presentations. Analysis of these documents provided an overview of } \\
\text { the issues authorities sought to communicate and the information they } \\
\text { wished to be explicitly known. The researcher also read and analysed the } \\
\text { documents produced by the pilot projects she focused on throughout her } \\
\text { fieldwork. }\end{array}$ \\
\hline
\end{tabular}

\section{Type of information source : actions and interactions}

\begin{tabular}{|l|l|}
\hline $\begin{array}{l}\text { Data } \\
\text { collection } \\
\text { method }\end{array}$ & Additional information \\
\hline $\begin{array}{l}\text { Direct } \\
\text { observation }\end{array}$ & $\begin{array}{l}\text { The researcher attended several types of meetings as an external observer } \\
\text { and took field notes for every one of those. In total, she attended } 67 \text { meet- } \\
\text { ings, which correspond to } 148 \text { hours of observation. She spent } 105 \text { hours } \\
\text { observing the meetings of two pilot projects (e.g., preparatory meetings } \\
\text { during the conceptualisation phase, follow-up meetings during the execu- } \\
\text { tion phase): 35 hours for the first project and 70 hours for the second. } \\
\text { The researcher also attended specific meetings, called plenary sessions and } \\
\text { "intervisions", organised by the public authorities (43 hours). } \\
\text { Regarding the analysis of the collected information, the notes taken were } \\
\text { read several times to have a precise and global understanding of the course } \\
\text { of events and also in order to put into perspective the qualitative data col- } \\
\text { lected with those gathered during the interviews. }\end{array}$ \\
\hline
\end{tabular}




\section{Type of information source : discourses}

\begin{tabular}{|c|c|}
\hline $\begin{array}{l}\text { Data } \\
\text { collection } \\
\text { method }\end{array}$ & Additional information \\
\hline $\begin{array}{l}\text { Semi- } \\
\text { structured } \\
\text { interviews }\end{array}$ & $\begin{array}{l}\text { Twenty-four semi-structured interviews were conducted by the researcher } \\
\text { with different categories of actors identified thanks to the snowball effect. } \\
\text { These were people with whom the researcher had no prior relationship: } \\
\text { - policy-advisers and public officials involved in devising and imple- } \\
\text { menting the new policy ( } \mathrm{n}=9 \text { ) } \\
\text { - pilot project coordinators ( } \mathrm{n}=8 \text { ) } \\
\text { - different pilot project stakeholders, e.g., general practitioners, } \\
\text { nurses, social workers, etc. ( } \mathrm{n}=7 \text { ) } \\
\text { The purpose of meeting these people was to identify, through their dis- } \\
\text { course, their formal and informal roles, the way they personally experi- } \\
\text { enced the process, their knowledge (what they knew, but also what they } \\
\text { did not know) and their feelings about it. A new interview guide was writ- } \\
\text { ten for each of them. These interviews lasted between } 33 \text { and } 98 \text { min- } \\
\text { utes; they were all fully recorded, transcribed, read several times and then } \\
\text { analysed manually through open coding, again by the researcher working } \\
\text { alone. Open coding is a method of analysis from grounded theory meth- } \\
\text { odology that allows the emergence of ad hoc core categories identified in } \\
\text { the empirical material through repeated successive readings (Bryant \& } \\
\text { Charmaz, 2011). }\end{array}$ \\
\hline
\end{tabular}




\section{Appendix 3 - Integrated care components}

\section{8 components of integrated care}

\begin{tabular}{|c|c|}
\hline 1. & Empowerment \\
\hline 2. & Support for caregivers \\
\hline 3. & Case-management \\
\hline 4. & Maintenance at work as well as educational, professional and social reintegration \\
\hline 5. & Prevention \\
\hline 6. & Dialogue and coordination \\
\hline 7. & Care continuity (extramural, intramural and transmural) \\
\hline 8. & $\begin{array}{l}\text { Accenting the experience of patients and families' organisations and of mutual } \\
\text { health insurances }\end{array}$ \\
\hline 9. & Integrated electronic health records \\
\hline 10. & Multidisciplinary guidelines \\
\hline 11. & Development of a quality culture \\
\hline 12. & Adaptation of financing systems \\
\hline 13. & Risk stratification and resources mapping \\
\hline 14. & Change management \\
\hline 15. & $\begin{array}{l}\text { Training for professionals regarding empowerment and multidisciplinary collabo- } \\
\text { ration }\end{array}$ \\
\hline 16. & Continuing training regarding integrated care \\
\hline 17. & Evaluation of the system performance \\
\hline 18. & Attractiveness of professions \\
\hline
\end{tabular}

Source : Belgian Ministry of Social Affairs and Public Health, 2015, p. 10 